\title{
Process standardization and development of honey based aonla (Phyllanthus emblica) candy
}

\author{
S. D. Katke, P. S. Patil and G. R. Pandhare
}

The present investigation focuses on standardization the process for preparation of aonla candy using honey. Further, sugar was completely replaced with honey. It can be concluded that honey syrup concentration treatments $\left(45^{\circ} \mathrm{Bx}, 50^{\circ} \mathrm{Bx}\right.$ and $70^{\circ} \mathrm{Bx}$ ) along with 02 per cent alum was found to be suitable to improve the quality of candy. Moreover, cabinet tray drying $\left(60^{\circ} \mathrm{C}\right)$ was selected on the basis of chemical composition and organoleptic evaluation for commercial feasibility. Eventually, the prepared candies can be properly stored in standing pouch upto 02 to 03 months without affecting their sensory quality attributes. This honey based aonla candy is nutraceutical rich product that have high energy value and additional health benefits. Therefore, the developed aonla candies can be one of the upcoming value added food products. They may have a good commercial market and subject to catch attention of customers of every age group.

Key Words : Aonla candy, Amla candy, Phyllanthus emblica, Honey based candy, Indian gooseberry

How to cite this article : Katke, S.D., Patil, P.S. and Pandhare, G.R. (2018). Process standardization and development of honey based aonla (Phyllanthus emblica) candy. Food Sci. Res. J., 9(2): 311-317, DOI : 10.15740/HAS/FSRJ/9.2/311-317. Copyright@ 2018: Hind Agri-Horticultural Society.

Associate Authors' :

P. S. Patil, Department of Food Science and Technology, MIT College of Food Technology, Aurangabad (M.S.) India

G.R. Pandhare, Department of Chemical Technology, Dr. Babasaheb Ambedkar Marathwada University, Aurangabad (M.S.) India 